\title{
Does pregnancy influence eye parameters? Assessment of choroidal thickness using EDI-OCT before and after labour depending on the way of delivery method
}

\author{
Karol Taradaj ${ }^{1,2} \mathbb{D}$, Tomasz Ginda ${ }^{1,2} \mathbb{D}$, Piotr Maciejewicz ${ }^{1} \mathbb{D}$, Barbara Suchonska ${ }^{3}$, \\ Miroslaw Wielgos ${ }^{3}$, Dariusz Kecik¹ , Bozena Kociszewska-Najman² (D) \\ ${ }^{1}$ Medical University of Warsaw, Faculty of Medicine, Department of Ophthalmology, Warsaw, Poland \\ ${ }^{2}$ Medical University of Warsaw, Faculty of Health Sciences, Department of Neonatology, Warsaw, Poland \\ ${ }^{3}$ Medical University of Warsaw, Faculty of Medicine, Department of Obstetrics and Gynaecology, Warsaw, Poland
}

\begin{abstract}
Objectives: The aim of this study is to assess the choroidal thickness (CT) with use of EDI-OCT in patients before and after delivery depending on the mode of delivery.

Material and methods: The study involved 146 eyes of 73 patients aged 20-34 years, after natural labour (66 eyes) and C-section (80 eyes). Main inclusion criteria: Informed consent to participate in the study, age 18-35 years, single pregnancy, spherical refraction error -4.00 to $+4.00 \mathrm{D}$, no eye pathologies, no surgery and ophthalmic procedures-including refractive surgery, childbirth after 36 weeks of pregnancy, BCVA $=1.0$. Patients were examined twice: in $36 \mathrm{WG}$ and on $6^{\text {th }}$ week after the birth. All examinations were carried out between 8:00 am and 10:00 am in order to avoid daily cycle fluctuations. CT measurements were made manually by two independent researchers at: subfoveal and $500 \mu \mathrm{m}, 1000 \mu \mathrm{m}, 1500 \mu \mathrm{m}$, $3000 \mu \mathrm{m}$ temporally and nasally. The student's t-test was made.

Results: In C-section group CT differences before and after delivery were statistically significant in 7/9 of the analysed areas. Mean subfoveal choroidal thickness was $370.86 \mu \mathrm{m}$ vs $388.71 \mu \mathrm{m}$ in $36 \mathrm{WG}$ and in $6^{\text {th }}$ week postpartum respectively $(p=0.0003)$. In women after natural labour, differences were statistically significant in $3 / 9$ of the analysed areas. Mean subfoveal choroidal thickness was $303.27 \mu \mathrm{m}$ vs $308,34 \mu \mathrm{m}$ in $36 \mathrm{WG}$ and in $6^{\text {th }}$ week postpartum respectively $(p=0.4800)$.

Conclusions: The thickness of the choroid was lower in women in 36 WG in comparison to $6^{\text {th }}$ week after birth. Changes in the thickness of the choroid are particularly noticeable in women after caesarean section.
\end{abstract}

Key words: pregnancy; caesarean section; natural childbirth; choroid; optical coherence tomography

Ginekologia Polska 2020; 91, 11:668-673

\section{INTRODUCTION}

Pregnancy, being a special physiological condition of a woman's organism, is characterized by a variety of changes in many systems and organs. In recent years there has been a growing trend in research to investigate the influence of pregnancy and labour on the visual system [1].

The choroid is one of the most vascularized tissues in our body. Despite its small size, it is the structure with the highest blood flow in relation to volume. Until recently, there were no diagnostic methods available to create clear image of the choroid, therefore its physiology has not yet been fully understood. Examination of the choroid became available after Spaide's et al. [2] introduction of EDI-OCT modification, which, thanks to its high resolution and great- er depth of scanning, allowed to visualize the structure of the choroid. This discovery led to an increased interest in the choroid physiology and intensified clinical trials on the influence of numerous factors and pathological conditions on the morphology of choriocapillaris. Among the factors that correspond to the thickness of choroid (CT, choroidal thickness) the most important are: vascular diseases such as diabetic retinopathy, hypertension, AMD and also AL, CCT, IOP, age and refractive error [3-5] It has been shown that CT changes during the 24-hour cycle [6, 7]. Ulaş has also shown that $\mathrm{CT}$ fluctuates between phases of the menstrual cycle [8], which may indicate a hormonal background for described changes. This interpretation is supported by studies of Wickham et al. [9], who showed the presence of female 
sex hormone receptors mRNA in choroid cells. For a long time, it was believed that unlike retina and anterior vascular membrane, choroid has no autoregulatory mechanism and its physiology is controlled mainly by autonomic nervous system mediators and hormonal stimulation. Recent reports indicate that small vessels of the choroid can have some degree of its own blood flow regulation, but the mechanism of this phenomenon has not yet been fully explained [10].

Results of recent studies on the influence of pregnancy and childbirth on the anterior segment of the eye showed changes, such as the increase in central corneal thickness, temporary change in spherical refraction, increase of depth of anterior chamber [11, 12], and resulting indirect drop in intraocular pressure [13-16]. Mentioned changes are interpreted as hormonally related, which is supported by in vitro studies. The presence of estrogen and progesterone receptors mRNA in the stroma of cornea has been shown. Other changes, such as the change in endothelial cell density [17], the appearance of transient astigmatism [11], or changes in corneal biomechanical parameters $[14,15,18,19]$ are controversial and require further research. In recent years, several studies have been published, assessing the impact of pregnancy and childbirth on the thickness of the choroid. However, the results obtained by the researchers are divergent and the physiological background of these changes is still unclear.

This study aims to answer the following research questions: Is the thickness of the choroid different in patients in the third trimester of pregnancy compared to post-delivery period? Does the birth method affect the thickness of the choroid?

\section{MATERIAL AND METHODS}

This prospective research was carried out in accordance with the Helsinki Declaration. Patients who agreed to participate in the study gave their written, informed consent after explanation of the nature and possible consequences of the study. The research was conducted in the period from October 2016 to September 2019.The study involved 146 eyes of 73 patients aged 20-34 years. The study involved both pregnant women giving birth vaginally (66 eyes of 33 patients) and women who gave birth by caesarean section (80 eyes of 40 patients). The preliminary qualification procedure was carried out, as part of which the following tests were performed:

- interviews: ophthalmological and obstetrical,

- BCVA to far and near vision using standardized Snellen tables,

- assessment of the anterior and posterior segment of the eye in biomicroscopy,

- auto kerato-refractometer.

Patients who met the criteria for inclusion were recruited to the research group - Table 1.
Patients qualified to participate in the project were examined twice: in 36 WG and 6 weeks after the delivery. The tests were carried out on the SPECTRALIS ${ }^{\circ}$ OCT (Heidelberg Engineering) device. Optical coherent tomography of the choroid was performed. The measurement of the choroidal thickness was performed according to the protocol presented below. Anatomical limitations of the choroid were determined as:

- upper limit: the boundary between the end of the retinal pigment epithelium and Bruch's membrane (the lower edge of the hyperreflex line),

- lower limit: border between sclera and choroid

Measurements were made manually each time by two independent researchers. Protocol included manual measurements at 9 spots: subfoveal, 500, 1000, 1500, $3000 \mu \mathrm{m}$ temporally and nasally from the fovea, respectively. The measurement diagram is illustrated in Figure 1.

The researchers were not informed about whether the result presents a measurement from the third trimester of pregnancy or from the period after childbirth. All examina-

\begin{tabular}{|c|c|}
\hline Inclusion criteria & Exclusion criteria \\
\hline $\begin{array}{l}\text { Informed consent to participate } \\
\text { in the study }\end{array}$ & $\begin{array}{l}\text { No informed consent to } \\
\text { participate in the study }\end{array}$ \\
\hline Age $18-35$ years old & 18 years $>$ Age $>35$ years old \\
\hline $\begin{array}{l}\text { Physiological delivery or } \\
\text { cesarean section }\end{array}$ & Complicated pregnancy \\
\hline Single pregnancy & Multiple pregnancy \\
\hline $\begin{array}{l}\text { Refraction error } \\
-4.00 \text { to }+4.00 \mathrm{D} \text { sph. }\end{array}$ & $\begin{array}{l}\text { Operative vaginal delivery- OVD: } \\
\text { vacuum and forceps delivery }\end{array}$ \\
\hline $\begin{array}{l}\text { Good cooperation during } \\
\text { research }\end{array}$ & $\begin{array}{l}\text { Pregestational diabetes melitus } \\
\text { And gestational diabetes melitus }\end{array}$ \\
\hline No eye diseases & Hypertension in pregnancy \\
\hline $\begin{array}{l}\text { No surgery and/or ophthalmic } \\
\text { procedures in history }\end{array}$ & Preeclapsja \\
\hline $\begin{array}{l}\text { Childbirth after } 36 \text { weeks of } \\
\text { gestation }\end{array}$ & $\begin{array}{l}\text { Intrauterine growth } \\
\text { restriction - IUGR }\end{array}$ \\
\hline $\begin{array}{l}\text { Distance BCVA: LogMAR = 0.0, } \\
(\mathrm{V}=20 / 20)\end{array}$ & $\begin{array}{l}\text { Defective spherical refraction } \\
\text { outside of the scope of inclusion } \\
\text { criteria }\end{array}$ \\
\hline \multirow[t]{6}{*}{ Near BCVA: $\mathrm{Sn}=0.5 / 30 \mathrm{~cm}$} & $\begin{array}{l}\text { Lack of cooperation from the } \\
\text { patient }\end{array}$ \\
\hline & $\begin{array}{l}\text { Active disease of the anterior or } \\
\text { posterior segment of the eye }\end{array}$ \\
\hline & $\begin{array}{l}\text { Condition after ophthalmic } \\
\text { operations or surgeries, } \\
\text { refractive procedure performed }\end{array}$ \\
\hline & $\begin{array}{l}\text { Premature delivery }<36 \text { weeks } \\
\text { gestation }\end{array}$ \\
\hline & $\begin{array}{l}\text { Distance BCVA: LogMAR }>0.0 \text {, } \\
(\mathrm{V}<20 / 20)\end{array}$ \\
\hline & Near BCVA: $>0.5 / 30 \mathrm{~cm}$ \\
\hline
\end{tabular}




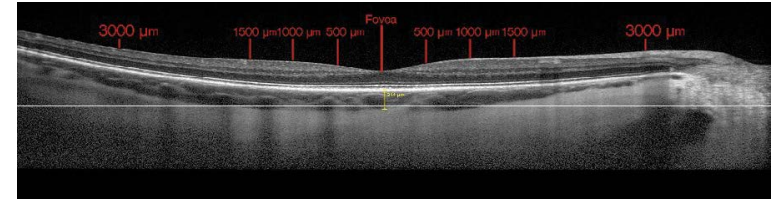

Figure 1. Measurements method

tions were carried out in the morning between 8:00 am and 10:00 am in order to avoid fluctuations related to the daily cycle.

For the analysis of the results, the values of parameters being the arithmetic mean of the measurements obtained by both researchers were used. The results were analysed statistically using StatSoft Statistica 13.1. All the results were presented as an average \pm standard deviation. Before starting the analysis, the conditions for parametric tests were checked. The normality of decomposition was checked by the Shapiro-Wilk test and the homogeneity of variance by the Leaven test. Because the above assumptions were met, the analysis of significance of differences was carried out with the student's t-test for dependent samples. The $p<0.05$ was assumed to be statistically significant.

\section{RESULTS}

Table 2 presents detailed results of $\mathrm{CT}$ analysis in nine areas: subfoveal, 500, 1000, 1500, $3000 \mu \mathrm{m}$ temporal and nasal from the fovea. The results are presented as mean and standard deviation $(\mu \mathrm{m})$. The table presents a comparison of CT between groups of women after natural labour and $C$-section with the level of significance $p$ of the Student's t-test.

Regardless of the delivery method and the analysed area of the choroid, the mean and standard deviation of choroid thickness were lower in women in 36 WG in comparison to 6th week after birth. However, these differences in CT before and after delivery were not statistically significant in all areas. In addition, a significant difference was observed depending on the delivery method of pregnancy. On the basis of t-Student's analysis it was shown that in Caesarean section group CT changes before and after delivery are statistically significant $(p<0.05)$ in $7 / 9$ of the analysed areas (subfoveal, Nasal: 500, 1000, 1500, $3000 \mu \mathrm{m}$, Temporal: 500, $1000 \mu \mathrm{m}$ ). In 2/9 areas (Temporal: 1500, $3000 \mu \mathrm{m}$ ), despite the observed trend, we did not observe significant differences $(p>0.05)$. Patients giving natural birth showed a similar trend as those giving birth with c-section, but the differences were not statistically significant in all regions of the choroid. In the group of women after natural labour, differences were statistically significant in 3/9 of the analysed areas (Nasal: 500, 1000, $1500 \mu \mathrm{m}$ ) and in 6/9 (Subfoveal, Nasal $3000 \mu \mathrm{m}$, Temporal: 500, 1000, 1500, $3000 \mu \mathrm{m}) \mathrm{p}>0.05$ was obtained. When measured at $3000 \mu \mathrm{m}$ nasally, the choroid was slightly thicker before childbirth than after delivery, but the mean difference was only $1.02 \mu \mathrm{m}$ and the difference was statistically insignificant ( $p=0.77$ ), so the difference is

\begin{tabular}{|c|c|c|c|c|c|c|c|c|c|c|c|c|c|c|}
\hline \multirow{2}{*}{$\begin{array}{l}\text { Location } \\
\text { ( } \mu \mathrm{m} \\
\text { from } \\
\text { fovea) }\end{array}$} & \multicolumn{2}{|c|}{$\begin{array}{l}\text { CS - group } \\
\text { before } \\
\text { delivery }\end{array}$} & \multicolumn{2}{|c|}{$\begin{array}{l}\text { CS - group } \\
\text { after delivery }\end{array}$} & \multirow{2}{*}{$\begin{array}{l}\text { Mean } \\
\text { differ- } \\
\text { ence } \\
(\mu \mathrm{m})\end{array}$} & \multirow{2}{*}{$\begin{array}{l}\text { SD } \\
(\mu \mathrm{m})\end{array}$} & \multirow{2}{*}{$\begin{array}{l}\text { p-value } \\
\text { (t-stu- } \\
\text { dent) }\end{array}$} & \multicolumn{2}{|c|}{$\begin{array}{l}\text { NL - group } \\
\text { before } \\
\text { delivery }\end{array}$} & \multicolumn{2}{|c|}{$\begin{array}{l}\mathrm{NL} \text { - group } \\
\text { after delivery }\end{array}$} & \multirow{2}{*}{$\begin{array}{l}\text { Mean } \\
\text { differ- } \\
\text { ence } \\
(\mu \mathrm{m})\end{array}$} & \multirow{2}{*}{$\begin{array}{l}\text { SD } \\
(\mu \mathrm{m})\end{array}$} & \multirow{2}{*}{$\begin{array}{l}\text { p-value } \\
\text { (t-stu- } \\
\text { dent) }\end{array}$} \\
\hline & $\begin{array}{l}\text { Mean } \\
(\mu \mathrm{m})\end{array}$ & $\begin{array}{l}\text { SD } \\
(\mu \mathrm{m})\end{array}$ & $\begin{array}{l}\text { Mean } \\
(\mu \mathrm{m})\end{array}$ & $\begin{array}{l}\text { SD } \\
(\mu \mathrm{m})\end{array}$ & & & & $\begin{array}{l}\text { Mean } \\
(\mu \mathrm{m})\end{array}$ & $\begin{array}{l}\text { SD } \\
(\mu \mathrm{m})\end{array}$ & $\begin{array}{l}\text { Mean } \\
(\mu \mathrm{m})\end{array}$ & $\begin{array}{l}\text { SD } \\
(\mu \mathrm{m})\end{array}$ & & & \\
\hline $\mathrm{SFCT}$ & 370.86 & 100.92 & 388.71 & 96.01 & -17.86 & 40.95 & 0.0003 & 303.27 & 88.09 & 308.34 & 112.62 & -5.07 & 47.51 & 0.4800 \\
\hline $\begin{array}{l}\text { Nasal } \\
500 \mu \mathrm{m}\end{array}$ & 348.36 & 96.85 & 367.48 & 97.93 & -19.12 & 32.73 & 0.0000 & 276.66 & 80.34 & 295.52 & 105.42 & -18.86 & 47.62 & 0.0119 \\
\hline $\begin{array}{l}\text { Nasal } \\
1000 \mu \mathrm{m}\end{array}$ & 325.25 & 92.73 & 340.6 & 95.27 & -15.35 & 31.36 & 0.0001 & 256.52 & 78.69 & 275.2 & 100.67 & -18.68 & 53.06 & 0.0243 \\
\hline $\begin{array}{l}\text { Nasal } \\
1500 \mu \mathrm{m}\end{array}$ & 281.21 & 85.36 & 300.14 & 93.08 & -18.94 & 92.07 & 0.0000 & 224.86 & 74.3 & 241.5 & 91.18 & -16.64 & 35.14 & 0.0031 \\
\hline $\begin{array}{l}\text { Nasal } \\
3000 \mu \mathrm{m}\end{array}$ & 156.75 & 56.92 & 171.68 & 79.11 & -14.92 & 56.34 & 0.0228 & 130.61 & 53.09 & 129.59 & 49.14 & 1.02 & 22.96 & 0.7690 \\
\hline $\begin{array}{l}\text { Temporal } \\
500 \mu \mathrm{m}\end{array}$ & 362.78 & 100.44 & 378.9 & 100.02 & -16.12 & 53.87 & 0.0105 & 291.23 & 83.29 & 302.93 & 108.38 & -11.7 & 47.08 & 0.1064 \\
\hline $\begin{array}{l}\text { Temporal } \\
1000 \mu \mathrm{m}\end{array}$ & 352.58 & 96.54 & 363.97 & 99.448 & -11.39 & 42.5 & 0.0213 & 293.32 & 79.95 & 299.07 & 105.83 & -5.75 & 41.29 & 0.3607 \\
\hline $\begin{array}{l}\text { Temporal } \\
1500 \mu \mathrm{m}\end{array}$ & 340.09 & 96.71 & 344.87 & 101.55 & -4.78 & 39.92 & 0.3003 & 297.68 & 81.67 & 300.59 & 96.08 & -2.91 & 41.26 & 0.6424 \\
\hline $\begin{array}{l}\text { Temporal } \\
3000 \mu \mathrm{m}\end{array}$ & 294.04 & 84.61 & 298.73 & 92.32 & -4.7 & 53.83 & 0.4492 & 268.73 & 51.96 & 277.75 & 75.97 & -9.02 & 43.48 & 0.1758 \\
\hline
\end{tabular}

CS: group (cesarean section group); NL: group (natural labour group) 
within the limits of measurement error (SD for this measurement $=22.96 \mu \mathrm{m}$ ).

The results allow us to conclude that the decrease in the thickness of the choroid after delivery compared to the third trimester of pregnancy is significantly more noticeable in women after $\mathrm{C}$-section than in women after vaginal delivery.

\section{DISCUSSION}

The lack of an unambiguous mechanism determining the character of changes in the thickness of choroid during pregnancy and after labour makes the subject controversial and worth taking an effort to conduct our own research project to clarify conflicting data [20].

Our study is the largest prospective study available in the literature (143 eyes), comparing the thickness of the choroid before and after childbirth. Our results are in opposition to the results of some researchers, but the methods of group selection and research schemes published in the literature are not identical. Choroid in pregnant patients was examined by many authors [1, 4, 11, 20, 27-33]. However, most of them [1, 11, 27-32] were clinical-control cohort examinations in which the thickness of choroid of pregnant women was compared to other, non-pregnant women. Such a study method does not allow obtaining objective results due to individual variation in the thickness of the choroid.

Dadaci et al. [28] examined 54 eyes of 27 patients in the first and third trimester of pregnancy. They showed that the choroid in the first trimester of pregnancy is thicker than in the third trimester. The authors did not perform postpartum tests, but instead used a control group of 50 eyes of 25 non-pregnant women. In this way, they found that the thickness of the choroid in the third trimester was higher than in non-pregnant patients (control group). Results [28] show the trend of CT changes during pregnancy, highlighting the differences between $1^{\text {st }}$ and $3^{\text {rd }}$ trimester, which is a great value of the work of these authors, but in our opinion those results do not allow to determine the direction of CT changes until the end of postpartum confinement, which was done in our work. In order to precisely trace changes in the thickness of the choroid during pregnancy, it is necessary to examine the same group of patients before and after childbirth as we have done in our study. Only such an examination scheme will allow to obtain objective results.

Goktas et al. [30] conducted a study in which they compared the thickness of the choroid in four groups of 30 eyes each, respectively in: $1^{\text {st }}, 2^{\text {nd }}$ and $3^{\text {rd }}$ trimester of pregnancy and control group. They found that the thickness of the choroid was highest in the $2^{\text {nd }}$ trimester with no increase of this parameter in the $1^{\text {st }}$ and $3^{\text {rd }}$ trimester of pregnancy compared to the control group. CT is a parameter of high individual volatility and in our opinion more reliable results would bring prospective studies.
Kara et al. [27] conducted a large study of 100 pregnant women, which they compared with the control group - non pregnant women. CT was measured only in subfoveal region, and the study group consisted of pregnant women with no distinction between trimesters. Considering the results of other researchers such as Goktas et al. [30] there is a clear difference in $\mathrm{CT}$ measured at different stages of pregnancy. The paper provides some information about mean CT values in particular trimesters of pregnancy, but it does not allow to determine the direction and dynamics of changes of this parameter.

Takahashi et al. [4, 20] and Ulusoy et al. [33] were the only ones who have done prospective study and examine the same group of women during pregnancy and after childbirth, so their results deserve special attention in this discussion.

Takahashi et al. [20] recruited patients in the $1^{\text {st }}$ trimester of pregnancy and conducted long-term observation based on four measurements: in the $1^{\text {st }}, 3^{\text {rd }}$ trimester, shortly after childbirth and one month after childbirth. By examining 62 eyes they showed that the CT was highest in the $1^{\text {st }}$ trimester, decreased in the $3^{\text {rd }}$ trimester and remained at a similar level to the first month after birth. This is a remarkably interesting study due to the fact that the authors have traced the changes in CT from the initial period of pregnancy to the first month after birth. It should be noted, that in comparison to our work, in which we examined 146 eyes in total, Takahashi et al. [20] have examined a relatively small group. In contrast to our study, they did not show any significant differences between CT in the $3^{\text {rd }}$ trimester and the first month after childbirth $(p>0.05)$. While our team showed that the choroid is thinner in the third trimester of pregnancy compared to the period after delivery $(p<0.05)$. Takahashi et al. [20] performed the last CT measurement 4 weeks after birth, and our team- 6 weeks. This may be of clinical importance as the regression of postpartum physiological changes usually occurs 6-7 weeks after birth. Takahashi et al. [20] provide valuable information on the direction of CT changes from the $1^{\text {st }}$ trimester of pregnancy to the $4^{\text {th }}$ week after birth, but do not determine the nature of the changes at a later stage. Our research shows that the CT may increase in relation to the values in the $3^{\text {rd }}$ trimester after the end of the postpartum period, as a result of a natural regression of postpartum changes in the woman's body, leading to the return of the pre-pregnancy choroid morphology.

The study of Ulusoy et al. [33] is the second of three prospective studies so far available in the literature, in which the same patients were examined before and after labour. The same study scheme was used in our work and by Takahashi et al. [20] Like us, he also examined women in 36 WG, but carried out a follow-up 3 months after the birth. SFCT was higher in the third trimester of pregnancy than three months 
after the birth $(p<0.05)$, which does not agree with the results of our studies, which show that SFCT is lower before labour in comparison to period after delivery. It should be noted, however, that statistically significant differences were obtained in women giving birth by $\mathrm{C}$-section $(\mathrm{p}<0.05)$. In case of vaginal delivery, despite the preserved tendency, the differences were not statistically significant $(p>0.05)$. Ulusoy et al. [33] did not specify in their methodology the type of birth, which, according to our research, is important for measuring $C T$. In the remaining regions results [33] were the same as ours - the choroid was thinner in 36WG than after childbirth, but differences were not statistically significant ( $p>0.05$ ). If we do not consider the method of delivery, our research shows that the choroid is thinner in 36 WG than on $6^{\text {th }}$ week after birth. However, after two separate analyses, depending on the method of delivery, these differences are most clearly seen and statistically significant, particularly in the group of women after C-sections. Perhaps the timing of the follow-up by Ulusoy et al. [33], which was carried out twice as late ( 12 weeks) as in the case of our follow-up ( 6 weeks), affects the CT value after birth.

We are the only team in the world to measure women's choroid before and after childbirth, differentiating the results according to the method of delivery. We decided that the prospective study of the same patients have greater scientific value, due to the fluctuation of individual thickness of the choroid. It is known that as soon as the $1^{\text {st }}$ trimester of pregnancy, the peripheral resistance of vessels decreases and the blood flow in the choroid increases during the $1^{\text {st }}$ $-2^{\text {nd }}$ trimester of pregnancy [34]. As pregnancy progresses, the volume of circulating blood increases steadily, increasing by $40 \%$ in the $3^{\text {rd }}$ trimester in comparison to pre-pregnancy levels. As can be seen from the work of Thornburg et al. [35], blood especially at the end of pregnancy is redistributed to important organs, such as the uterus, breast glands and kidneys. Moreover, as it results from the work of Dahle et al. [36], in the third trimester of pregnancy, mainly between 37 and 39WG, the number of adrenergic alpha-1 receptors in a woman's body increases, which is supposed to prepare for the initiation of childbirth. As reported by Dadaci et al. [28] it is the increase in the activity of these receptors that may affect the redistribution of blood from the vascular system to other organs and the constriction of choriocapillaris, which may explain reduction of thickness of the choroid demonstrated in our study with use of OCT in the $3^{\text {rd }}$ trimester of pregnancy. Current knowledge does not allow us to explain why in the case of a caesarean section, there is a more pronounced increase in the thickness of the choroid after birth than in the case of natural childbirth. This is the most interesting conclusion from our work -that C-section may influence the visual organ. It is possible that future research will clarify the exact mechanism of this phenomenon.

\section{REFERENCES}

1. Liu Ru, Kuang GP, Luo DX, et al. Choroidal thickness in pregnant women: a cross-sectional study. Int J Ophthalmol. 2016; 9(8): 1200-1206, doi: 10.18240/ijo.2016.08.18, indexed in Pubmed: 27588276.

2. Spaide RF, Koizumi H, Pozzoni MC, et al. Enhanced depth imaging spectral-domain optical coherence tomography. Am J Ophthalmol. 2008; 146(4): 496-500, doi: 10.1016/j.ajo.2008.05.032, indexed in Pubmed: 18639219.

3. Zhang J, Wang $\mathrm{H}, \mathrm{Yu}$ Q, et al. Enhanced depth imaging optical coherence tomography: a new way measuring choroidal thickness in pregnant women. J Ophthalmol.2017; 2017:8296574, doi:10.1155/2017/8296574, indexed in Pubmed: 28630765.

4. Takahashi J, Kado M, Mizumoto K. Choroidal thickness in pregnant women measured by enhanced depth imaging optical coherence tomography. Jpn J Ophthalmol. 2013; 57: 435.

5. Chen W, Li Li, Zhang H, et al. Macular choroidal thickness in highly myopic women during pregnancy and postpartum: a longitudinal study. BMC Pregnancy Childbirth. 2018; 18(1):220, doi: 10.1186/s12884-018-1865-3, indexed in Pubmed: 29884130.

6. Chakraborty R, Read SA, Collins MJ. Diurnal variations in axial length, choroidal thickness, intraocular pressure, and ocular biometrics. Invest Ophthalmol Vis Sci. 2011; 52(8): 5121-5129, doi: 10.1167/iovs.11-7364, indexed in Pubmed: 21571673.

7. Usui S, Ikuno Y, Akiba M, et al. Circadian changes in subfoveal choroidal thickness and the relationship with circulatory factors in healthy subjects. Invest Ophthalmol Vis Sci. 2012; 53(4): 2300-2307, doi: 10.1167/iovs.11-8383, indexed in Pubmed: 22427554.

8. Ulaş F, Doğan U, Duran B, et al. Choroidal thickness changes during the menstrual cycle. Curr Eye Res. 2013; 38(11): 1172-1181, doi: 10.3109/02713683.2013.811258, indexed in Pubmed: 23841496.

9. Wickham LA, Gao J, Toda I, et al. Identification of androgen, estrogen and progesterone receptor mRNAs in the eye. Acta Ophthalmol Scand. 2000; 78(2): 146-153, doi: 10.1034/j.1600-0420.2000.078002146.x, indexed in Pubmed: 10794246 .

10. Kur J, Newman EA, Chan-Ling T. Cellular and physiological mechanisms underlying blood flow regulation in the retina and choroid in health and disease. Prog Retin Eye Res. 2012; 31(5): 377-406, doi: 10.1016/j. preteyeres.2012.04.004, indexed in Pubmed: 22580107.

11. Ataş $M$, Duru $N$, Ulusoy DM, et al. Evaluation of anterior segment parameters during and after pregnancy. Cont Lens Anterior Eye. 2014; 37(6): 447-450, doi: 10.1016/j.clae.2014.07.013, indexed in Pubmed: 25128198.

12. Taradaj K, Ginda T, Maciejewicz P, et al. Changes in the parameters of the anterior segment of the eye in pregnant women $\otimes$ literature review. Ginekol Pol. 2018; 89(3): 169-173, doi: 10.5603/GP.a2018.0028, indexed in Pubmed: 29664553.

13. Tin SS, Wiwanitkit V. Pregnancy and intraocular pressure. Indian J Ophthalmol. 2014; 62(12): 1174, doi: 10.4103/0301-4738.149154, indexed in Pubmed: 25579366.

14. Goldich $Y$, Cooper M, Barkana $Y$, et al. Ocular anterior segment changes in pregnancy. J Cataract Refract Surg. 2014; 40(11): 1868-1871, doi: 10.1016/j.jcrs.2014.02.042, indexed in Pubmed: 25217070.

15. Sen $E$, Onaran $Y$, Nalcacioglu-Yuksekkaya P, et al. Corneal biomechanical parameters during pregnancy. Eur J Ophthalmol. 2014; 24(3): 314-319, doi: 10.5301/ejo.5000378, indexed in Pubmed: 24170521.

16. Tolunay HE, Özcan SC, Şükür YE, et al. Changes of intraocular pressure in different trimesters of pregnancy among Syrian refugees in Turkey: A cross-sectional study. Turk J Obstet Gynecol. 2016; 13(2): 67-70, doi: 10.4274/tjod.40221, indexed in Pubmed: 28913094.

17. Örnek N, Özcan Dağ Z, Örnek K. Corneal endothelial cell density and morphology in different trimesters of pregnancy. Eye Contact Lens. 2018; 44 Suppl 1: S125-S130, doi: 10.1097//CL.0000000000000354, indexed in Pubmed: 28060145.

18. Naderan M, Jahanrad A. Anterior, posterior and biomechanical parameters of cornea during pregnancy in healthy eyes: a cohort study. Br J Ophthalmol. 2018; 102(3): 309-312, doi: 10.1136/bjophthalmol-2017-310247, indexed in Pubmed: 28756375.

19. Carlin A, Alfirevic Z. Physiological changes of pregnancy and monitoring Best Pract Res Clin Obstet Gynaecol. 2008; 22(5): 801-823, doi: 10.1016/j. bpobgyn.2008.06.005, indexed in Pubmed: 18760680.

20. Takahashi J, Kado M, Mizumoto K, et al. Changes in subfoveal choroidal thickness during pregnancy and after delivery. Ophthalmic Surg Lasers Imaging Retina. 2017; 48(10): 816-821, doi: 10.3928/2325816020170928-06, indexed in Pubmed: 29020425. 
21. Imamura $Y$, Fujiwara T, Margolis R, et al. Enhanced depth imaging optical coherence tomography of the choroid in central serous chorioretinopathy. Retina. 2009; 29(10): 1469-1473, doi: 10.1097/IAE.0b013e3181 be0a83, indexed in Pubmed: 19898183.

22. Maruko I, lidaT, Sugano Y, et al. Subfoveal choroidal thickness in fellow eyes of patients with central serous chorioretinopathy. Retina. 2011;31(8):16031608, doi: 10.1097/IAE.0b013e31820f4b39, indexed in Pubmed: 21487334.

23. Chung SEe, Kang SeW, Lee JH, et al. Choroidal thickness in polypoidal choroidal vasculopathy and exudative age-related macular degeneration. Ophthalmology. 2011; 118(5): 840-845, doi: 10.1016/j.ophtha.2010.09.012, indexed in Pubmed: 21211846.

24. Koizumi H, Yamagishi T, Yamazaki T, et al. Subfoveal choroidal thickness in typical age-related macular degeneration and polypoidal choroidal vasculopathy. Graefes Arch Clin Exp Ophthalmol. 2011; 249(8): 11231128, doi: 10.1007/s00417-011-1620-1, indexed in Pubmed: 21274555.

25. Maruko I, lida T, Sugano Y, et al. Subfoveal choroidal thickness after treatment of Vogt-Koyanagi-Harada disease. Retina. 2011; 31(3): 510-517, doi: 10.1097/IAE.0b013e3181eef053, indexed in Pubmed: 20948460.

26. Fong AHC, Li KKW, Wong D. Choroidal evaluation using enhanced depth imaging spectral-domain optical coherence tomography in Vogt-Koyanagi-Harada disease. Retina. 2011; 31(3): 502-509, doi: 10.1097/IAE.0b013e3182083beb, indexed in Pubmed: 21336069.

27. Kara N, Sayin N, Pirhan D, et al. Evaluation of subfoveal choroidal thickness in pregnant women using enhanced depth imaging optical coherence tomography. Curr Eye Res. 2014; 39(6): 642-647, doi: 10.3109/02713683.2013.855236, indexed in Pubmed: 24400952

28. Dadaci Z, Alptekin H, Oncel Acir N, et al. Changes in choroidal thickness during pregnancy detected by enhanced depth imaging optical coherence tomography. Br J Ophthalmol. 2015; 99(9): 1255-1259, doi: 10.1136/bjophthalmol-2014-306343, indexed in Pubmed: 25710725.
29. Sayin N, Kara N, Pirhan D, et al. Subfoveal choroidal thickness in preeclampsia: comparison with normal pregnant and nonpregnant women. Semin Ophthalmol. 2014; 29(1): 11-17, doi: 10.3109/08820538.2013.839813, indexed in Pubmed: 24380489.

30. Goktas S, Basaran A, Sakarya Y, et al. Measurement of choroid thickness in pregnant women using enhanced depth imaging optical coherence tomography. Arq Bras Oftalmol. 2014; 77(3): 148-151, doi: 10.5935/00042749.20140038, indexed in Pubmed: 25295899.

31. Kim JW, Park MH, Kim YJ, et al. Comparison of subfoveal choroidal thickness in healthy pregnancy and pre-eclampsia. Eye (Lond). 2016; 30(3): 349-354, doi: 10.1038/eye.2015.215, indexed in Pubmed: 26541086.

32. Rothwell RT, Meira DM, Oliveira MA, et al. Evaluation of choroidal thickness and volume during the third trimester of pregnancy using enhanced depth imaging optical coherence tomography: a pilot study. J Clin Diagn Res. 2015; 9(8): NC08-NC11, doi: 10.7860/JCDR/2015/12888.6402, indexed in Pubmed: 26435977.

33. Ulusoy DM, Duru N, Ataş M, et al. Measurement of choroidal thickness and macular thickness during and after pregnancy. Int J Ophthalmol. 2015; 8(2): 321-325, doi: 10.3980/j.issn.2222-3959.2015.02.19, indexed in Pubmed: 25938049.

34. Centofanti M, Migliardi R, Bonini S, et al. Pulsatile ocular blood flow during pregnancy. Eur J Ophthalmol. 2002; 12(4): 276-280, doi: 10.1177/112067210201200404, indexed in Pubmed: 12219996.

35. Thornburg KL, Jacobson SL, Giraud GD, et al. Hemodynamic changes in pregnancy. Semin Perinatol. 2000; 24(1): 11-14, doi: 10.1016/s01460005(00)80047-6, indexed in Pubmed: 10709851.

36. Dahle LO, Andersson RG, Berg G, et al. Alpha-adrenergic receptors in human myometrium: changes during pregnancy. Gynecol Obstet Invest. 1993; 36(2): 75-80, doi: 10.1159/000292600, indexed in Pubmed: 8225051. 